\title{
CNS siderosis and orthostatic headache as a delayed complication of spinal surgery
}

Figure $1 \quad$ Brain MRI

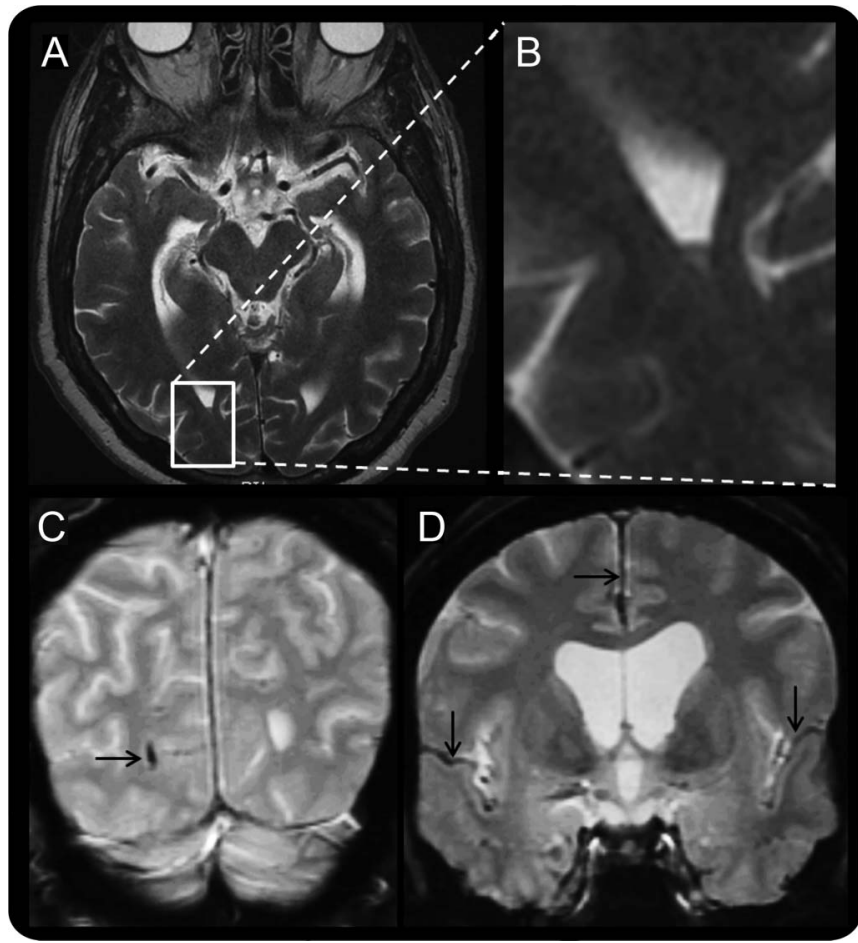

Trace intraventricular blood in the right occipital horn is seen as a fluid-fluid level on T2 fast spin echo sequence (A, B). T2* gradient echo sequence shows susceptibility artifact related to intraventricular blood (C) in addition to mild superficial siderosis, most prominently noted along the falx and sylvian fissures ( $D$, arrows).

A 61-year-old man presented with orthostatic headaches and asymmetric sensorineural hearing loss (ASNHL) 8 years after cervical laminoplasty. Percussion of his cervical spine elicited Lhermitte sign. Brain MRI demonstrated trace intraventricular blood and mild superficial siderosis (figure 1); digital subtraction angiogram had normal results. CT myelogram revealed fractured hardware puncturing adjacent dura with resultant CSF leak (figure 2).

Figure 2 Cervical CT myelogram

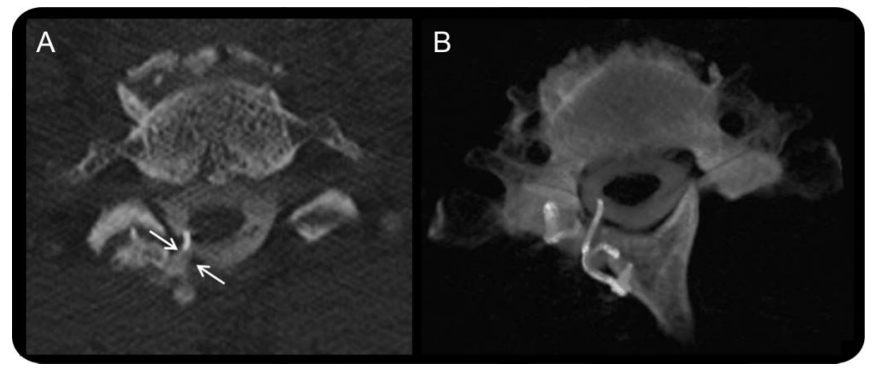

(A) Distal aspect of fractured and medially displaced laminoplasty plate is visible at C7. Its tip pierces the dura and approximates the dorsolateral spinal cord with resultant CSF leak (between arrows), accounting for patient's orthostatic headaches and Lhermitte sign on spine percussion. (B) 3D reconstruction of the dislodged plate. 
ASNHL or ataxia are typical presenting features of CNS siderosis, resulting from chronic cerebral or spinal subarachnoid hemorrhage, with characteristic brain MRI findings. ${ }^{1,2}$ CT myelogram in this patient identified the bleeding source and also explained his associated orthostatic headaches and Lhermitte sign.

Maxime O. Baud, MD, PhD, Alina Uzelac, DO, Cheryl A. Jay, MD, Jason F. Talbott, MD, PhD

From the University of California San Francisco and San Francisco General Hospital.

Author contributions: M.O.B. and C.A.J. evaluated the patient. A.U. interpreted the brain MRI. J.F.T. performed the CT myelogram. J.F.T. prepared the images and legends. M.O.B. wrote the manuscript. J.F.T., A.U., and C.A.J. finalized the manuscript. Study funding: No targeted funding reported.

Disclosure: The authors report no disclosures relevant to the manuscript. Go to Neurology.org for full disclosures.

Correspondence to Dr. Talbott: jason.talbott@ucs.edu

1. Kumar N. Superficial siderosis: associations and therapeutic implications. Arch Neurol 2007;64:491-496.

2. Fearnley JM, Stevens JM, Rudge P. Superficial siderosis of the central nervous system. Brain 1995;118:1051-1066.

\section{Seeking Papers for Neurology: Neuroimmunology \& Neuroinflammation}

The editors of Neurology ${ }^{\circledR}$ Neuroimmunology \& Neuroinflammation, an official journal of the American Academy of Neurology, have issued a call for papers and article submissions focused on original research and in-depth reviews of topics in neuroimmunology and neuroinflammation, including the full range of neurologic diseases. Clinical trials, instructive case reports, and small case series will also be featured. For more information or to make a submission, contact Editor Richard M. Ransohoff, MD, at NNNjournal@neurology.org.

\section{Visit the Neurology ${ }^{\circledR}$ Web Site at Neurology.org}

- Enhanced navigation format

- Increased search capability

- Highlighted articles

- Detailed podcast descriptions

- RSS Feeds of current issue and podcasts

- Personal folders for articles and searches

- Mobile device download link

- AAN Web page links

- Links to Neurology Now ${ }^{\circledR}$, Neurology Today ${ }^{\circledR}$, and Continuum ${ }^{\circledR}$

- Resident \& Fellow subsite

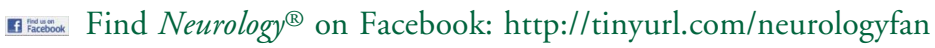

twitter Follow Neurolog $y^{\circledR}$ on Twitter: https://twitter.com/GreenJournal 


\section{Neurology}

CNS siderosis and orthostatic headache as a delayed complication of spinal surgery

Maxime O. Baud, Alina Uzelac, Cheryl A. Jay, et al.

Neurology 2014;83;2097-2098

DOI 10.1212/WNL.0000000000001028

\section{This information is current as of November 24, 2014}

\section{Updated Information \&} Services

References

Subspecialty Collections

Permissions \& Licensing

Reprints including high resolution figures, can be found at: http://n.neurology.org/content/83/22/2097.full

This article cites 2 articles, 0 of which you can access for free at: http://n.neurology.org/content/83/22/2097.full\#ref-list-1

This article, along with others on similar topics, appears in the following collection(s):

CT

http://n.neurology.org/cgi/collection/ct

Low pressure syndrome

http://n.neurology.org/cgi/collection/low_pressure_syndrome MRI

http://n.neurology.org/cgi/collection/mri

Subarachnoid hemorrhage

http://n.neurology.org/cgi/collection/subarachnoid_hemorrhage

Information about reproducing this article in parts (figures,tables) or in its entirety can be found online at:

http://www.neurology.org/about/about_the_journal\#permissions

Information about ordering reprints can be found online:

http://n.neurology.org/subscribers/advertise

Neurology ${ }^{\circledR}$ is the official journal of the American Academy of Neurology. Published continuously since 1951, it is now a weekly with 48 issues per year. Copyright @ 2014 American Academy of Neurology. All rights reserved. Print ISSN: 0028-3878. Online ISSN: 1526-632X.

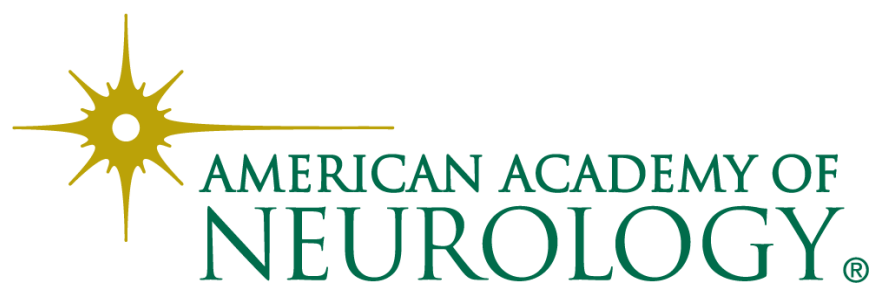

